\title{
RADIOACTIVE DEMONSTRATION OF DWPF PRODUCT CONTROL STRATEGY (U)
}

by M.K. Andrews, et al.

Westinghouse Savannah River Company

WSRC-TR- $-92-217$

Savannah River Site

Aiken, South Carolina 29808

DE93 002168

N. E. Bibler

This paper was prepared in connection with work done under Contract No. DE-AC09-89SR18035 with the U. S. Department of Energy. By acceptance of this paper, the publisher and/or recipient acknowledges the U. S. Government's right to retain a nonexclusive, royalty-tree license in and to any copyright covering this paper, along with the right to reproduce and to authorize othurs to reproduce all or part of the copyrighted paper.

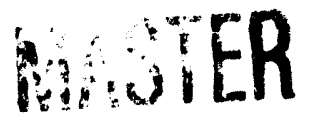




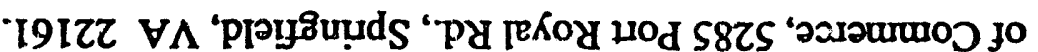

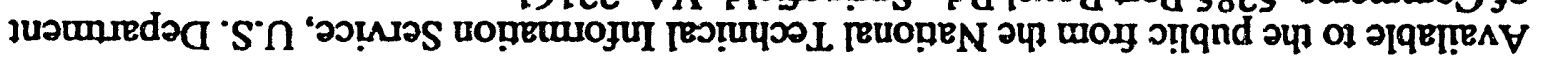

I0D8-929 SIA

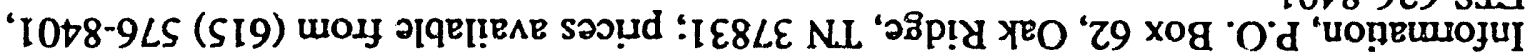

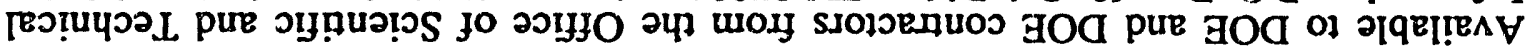

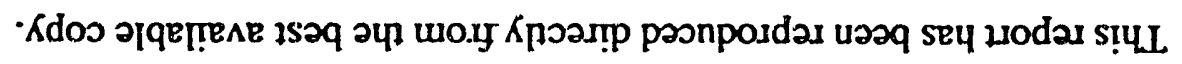

josjoul

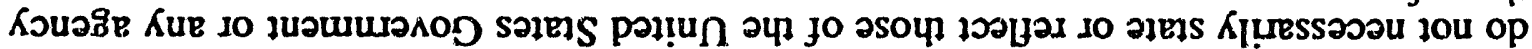

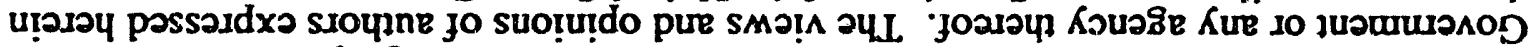

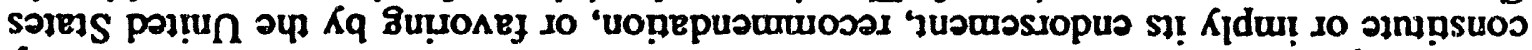

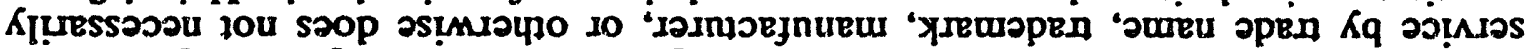

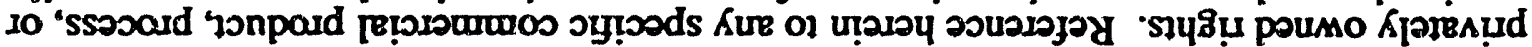

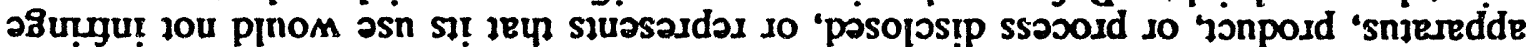

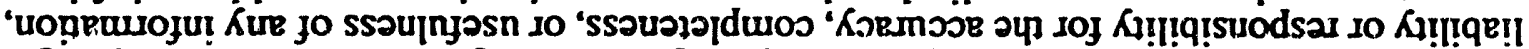

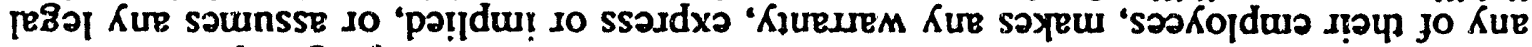

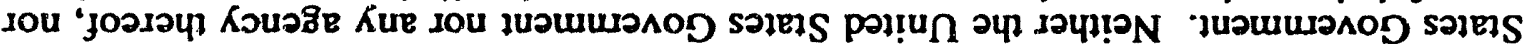

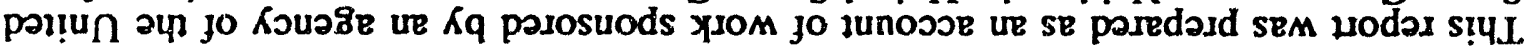

\section{8สพIVTวSIด}


WESTINGHOUSE SAVANNAH RIVER COMPANY SAVANNAH RIVER LABORATORY
WSRC $-T R-92-217$

REV. $\quad 0$

Keywords: DWPE, melter, PCCS

Retention Time: Permanent

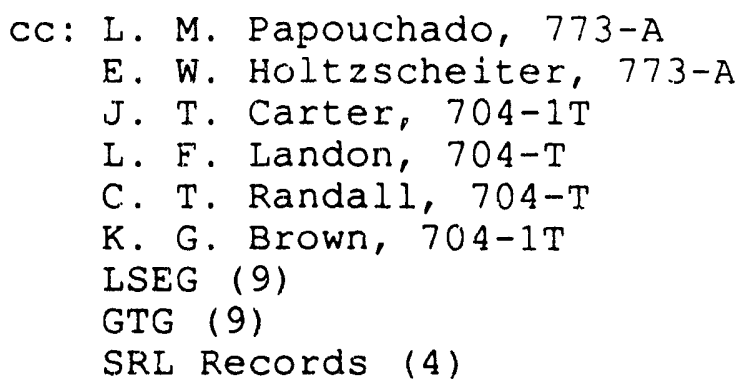

April 22, 1992

To: $\quad$ M. J. Plodinec

From: M. K. Andrews and N. E. Bibler

BADTOACTIYR DMMONSTRATION OF DHPF PRODUCT CONTROT STRATEGY (II)

\section{Summary}

The effectiveness of the product and process control strategies that will be utilized by the Defense Waste Processing Facility (DWPF) was demonstrated during a campaign in the Shielded celis Facility (SCF) of the Savannah River Technology Center (SRTC). The remotely operated process included the preparation of the melter feed, vitrification in a slurry-fed 1/100th scale melter and analysis of the glass product both for its composition and durability.

The campaign processed approximately $10 \mathrm{~kg}$ (on a dry basis) of radioactive sludge from Tank 51. This sludge is representative of the first batch of sludge that will be sent to the DWPE for immobilization into borosilicate glass. Additions to the sludge were made based on calculations using the Product composition Control system (PCCS). Analysis of the glass prociuced during the campaign showed that a durable glass was producer, with a composition similar to that predicted using the PCCS.

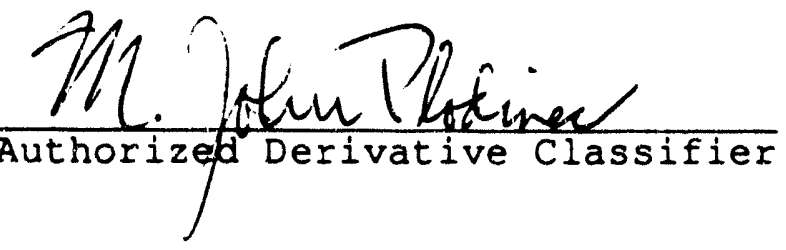




\section{Intreduction}

The Defense Waste Processing Facility (DWPE) at the Savannah River Site (SRS) will immobilize high-level nuclear waste by vitrifying it into a durable borosilicate glass. To ensure that this is achieved, specifications, such as the Product Consistency Specification, have been established. The Product Consistency Specification states that the glass produced must be more durable than the DWPE Environmental Assessment (EA) glass.

Since it is not possible to recycle glass that does not meet the specifications, glass sampling is of little value for control. Therefore, process and product control in the DWPF are based on a knowledge of the composition of the material in the melter feed tank. An extensive program, the Product Composition Control System (PCCS), has been developed for process and product control in the DWPF. 1 Using the PCCS, the necessary processing properties, melt viscosity and liquidus, as well as the durability of the final glass product can be predicted.

This paper describes the process control strategies used during the vitrification of radioactive waste from Tank 51 in the Shielded Cells Facility (SCF) of the Savannah River Technology Center (SRTC). Once the composition of the waste was determined, the PCCS was used to formulate the proper waste-frit composition. The waste was mixed with a glass-forming frit and fed to a remotely-operated joule-heated melter. The glass produced during this campaign was analyzed using DWPF analytical methods. The Product Consistency Test (PCT) was used to measure the durability of the glass.

\section{Bigh rerel raste Chemical composition}

There were two main components in this waste: radioactive sludge from SRS tank 51 and simulated Precipitate Hydrolysis Aqueous (PHA), the product of hydrolysis of cesium tetraphenylborate precipitate. To determine the composition of the waste, aliquots of slurry were dried, dissolved and the resulting solutions analyzed for radioactive and nonradioactive elements. The analytical methods are described in detail elsewhere. 2 The results for the significant elements are shown in Table 1 . The glass and feed slurries were so radioactive that the process had to be operated remotely using manipulators in the SCF. However, relative to the nonradioactive materials present, the radionuclides comprise only a small percentage of the mass of the waste and therefore do not affect the properties of the product or the vitrification process. Therefore, the radionuclides will not discussed in this paper. 
Table 1. Major Components in SRS Tank 51 sludge with PHA (Weight Percent Based on Dried sludge)

$\begin{array}{cccc}\text { Element } & \begin{array}{c}\text { Weight } \\ \text { Rercent }\end{array} & \text { Element } & \begin{array}{r}\text { Weight } \\ \text { Percent }\end{array} \\ \mathrm{Fe} & 23.11 & \mathrm{~B} & 0.72 \\ \mathrm{Al} & 6.34 & \mathrm{P} & 0.34 \\ \mathrm{Na} & 3.36 & \mathrm{Ni} & 0.32 \\ \mathrm{~K} & 2.37 & \mathrm{Cu} & 0.28 \\ \mathrm{Mn} & 2.29 & \mathrm{Ti} & 0.23 \\ \mathrm{U} & 2.07 & \mathrm{Cr} & 0.14 \\ \mathrm{Ca} & 1.67 & \mathrm{Hg} & 0.02 \\ \mathrm{Mg} & 0.85 & \mathrm{Th} & 0.03 \\ \mathrm{Si} & 0.75 & & \end{array}$

\section{Rroduat Control}

The PCCS was used to determine the type and amount of frit to combine with the waste for successful vitrification. The PCCS used a composition/leach test 7 lgorithm based on the MCC-1 test. The durability criterion used by the PCCS is that the glass must be more durable than the DWPF Environmental Assessment (EA) glass $\left(\Delta G_{h y d} \geq-7 \mathrm{kcal} / \mathrm{mol}\right)$. The composition recommended by the PCCS was thus predicted to be more durable than the EA glass. Appropriate sources of uncertainty were taken into account in making that determination. ${ }^{3}$ As will be discussed later, the PCT was used to determine durability rather than the MCC-1 test. However, since the durability criterion (glass product better than the EA glass) is the same, these results are directly applicable to the product consistency specification.

Due to excessive washing of the sludge in the SCF, sodium was depleted from the waste. Therefore, the PCCS also determined a remediation strategy using trim chemicals. Based on the composition of the waste, the program determined that a ratio of 68 Frit 202 oxides, $27 \%$ waste oxides and $5 \%$ sodium oxide should be combined to produce an acceptable feed. 4 Tsole 2 shows the PCCS predicted properties along with the allowable limits for these properties. These properties are far enough from the control limits to produce a feed that could be processed and would be durable. 
Table 2. Predicted Processing Properties for Tank 51 Sludge Glass Using the PCCS

Property
Viscosity (Poise)
Liquidus $\left({ }^{\circ} \mathrm{C}\right)$
Durability ( $\mathrm{kcal} / \mathrm{mol})$
Tio2 (wt 8 )
Cr203 (wt 8 )

Acceptable

$20-100$

$\leq 1050$

$\Delta$ Ghyd $\geq-7$

$\leq 1.0$

$\leq 3.0$
PCCS Predicted

1014

$-4.8$

0.15

0.08

\section{Melter Campaion}

Based on the composition determined by the PCCS, $18.99 \mathrm{~kg}$ of Erit 202 and $1.92 \mathrm{~kg}$ of NaNO3 were thoroughly combined with the 11.78 $\mathrm{kg}$ of hydrous oxides in the melter feed tank. The weight percent solids was adjusted to $40 \%$ which is close to the value that the DWPF expects to use. This feed was pumped from the melter feed tank through a water-cooled feed nozzle to the research melter at a rate of approximately $17 \mathrm{ml} / \mathrm{min}$.

The research melter is a slurry-fed joule heated melter with two pairs of Inconel electrodes providing the power to maintain a melt pool temperature of $1150^{\circ} \mathrm{C}$. The cylindrical melt chamber is eight inches in diameter and six inches deep and holds approximately ten kilograms of glass. Two additional heaters are located in the melter above the melt pool to provide supplemental heat which increases the melt rates by vaporizing water from the slurry feed. An off-gas system is connected to the melter to collect the water and other volatiles produced during vitrification. This melter and off-gas system were previously used to vitrify waste from SRS Tanks 8 and 12.5

Glass pouring is initiated by tilting the entire melter. The glass flows from the melt pool through a riser cut in the refractory, and out a heated pour spout into 0.5 liter stainless steel beakers. During the Tank 51 campaign, the melter ran continuously for 54 hours producing $31 \mathrm{~kg}$ of glass in 27 cans.

\section{Results}

Samples of glass were taken from the last can poured during the campaign. The last can was chosen since it would have a composition most representative of the feed. The can was sectioned and 1/2" slices from both the top and the bottom sections of the can were cut. Interior samples of the glass were taken from these slices to characterize by determining its composition and by leaching it according to the product Consistency Test (PCT) protocol. 
The glass composition of both the top and bottom sections of the can was measured by dissolving samples by sodium peroxide fusion and $\mathrm{HF} / \mathrm{HCl} / \mathrm{HNO}_{3}$ acids. The resulting solutions were analyzed by Inductively Coupled Plasma Excitation Spectroscopy and Atomic Absorption Spectroscopy. Multiple samples from each section were analyzed with little difference between the top and bottom sections. The average measured composition for the top and bottom sections, along with the value predicted by the PCCS, is shown in Table 3. The measured values for sodium and silicon are lower than predicted suggesting that too little frit was added to the feed.

Table 3. Predicted and Measured Glass Composition (Based on triplicate analyses unless otherwise indicated)

\begin{tabular}{|c|c|c|c|}
\hline OXIDE & PREDICTED & $\begin{array}{l}\text { TOP SECTION } \\
\text { MEASURED }\end{array}$ & $\begin{array}{l}\text { BOTTOM SECTION } \\
\text { MEASURED }\end{array}$ \\
\hline $\mathrm{CaO}$ & 0.95 & 1.26 & 1.25 \\
\hline $\begin{array}{l}\text { Mgo } \\
\text { MnO }\end{array}$ & $\begin{array}{l}1.93 \\
1.18\end{array}$ & $\begin{array}{l}2.04^{a} \\
1.57\end{array}$ & $\begin{array}{l}2.07^{b} \\
1.27\end{array}$ \\
\hline $\mathrm{Al}_{2} \mathrm{O}_{3}$ & 4.81 & $4.45 C$ & $4.50^{C}$ \\
\hline $\mathrm{Fe}_{2} \mathrm{O}_{3}$ & 13.23 & $12.9 \mathrm{a}$ & $13.1 \mathrm{~b}$ \\
\hline $\begin{array}{l}\mathrm{Ii}_{2} \mathrm{O} \\
\mathrm{Na}_{2} \mathrm{O}\end{array}$ & $\begin{array}{r}4.79 \\
10.72\end{array}$ & $\begin{array}{l}4.52^{a} \\
8.58\end{array}$ & $\begin{array}{l}4.58^{b} \\
8.45\end{array}$ \\
\hline $\mathrm{TiO}_{2}$ & 0.15 & $0.25^{a}$ & $0.26^{b}$ \\
\hline $\mathrm{B}_{2} \mathrm{O}_{3}$ & 6.36 & $6.20 c$ & $6.26 \mathrm{C}$ \\
\hline $\begin{array}{l}\mathrm{SiO}_{2} \\
\mathrm{~K}_{2} \mathrm{O} \\
\mathrm{UO}_{2} \\
\mathrm{Cr}_{2} \mathrm{O}_{3}\end{array}$ & $\begin{array}{r}53.09 \\
1.15 \\
0.93 \\
0.08\end{array}$ & $\begin{array}{c}46.9 c \\
1.45 \\
1.03 \\
0.28\end{array}$ & $\begin{array}{l}49.6 \quad c \\
1.41 \\
1.02 \\
0.27\end{array}$ \\
\hline $\begin{array}{l}\text { CuO } \\
\text { NiO }\end{array}$ & $\begin{array}{l}0.14 \\
0.16\end{array}$ & $\begin{array}{l}0.13^{a} \\
0.28\end{array}$ & $\begin{array}{l}0.13^{b} \\
0.27\end{array}$ \\
\hline
\end{tabular}

a Average of 6 analyses

baverage of 5 analyses

CAverage of 2 analyses

The Product Consistency Test (PCT) was used to determine the durability of the glass. The PCT is a crushed glass leach test at $90^{\circ} \mathrm{C}$. The releases of boron, lithium, sodium, potassium and silicon from the glass are measured in ASTM Type 1 water over a period of seven days. 6 The average concentrations and final pH values for the top and bottom sections are shown in Table 4. The concentration values obtained for the Tank 51 glass were compared to the results for the EA glass. As predicted, the Tank 51 glass is considerably more durable than the EA glass. The final $\mathrm{pH}$ values also indicate a greater durability for the Tank 51 glass. The glass from the Tank 51 campaign was determined to have more precise data than glass from earlier radioactive campaigns and comparable durabilities. 5 
Table 4. Average Concentrations, Standard Deviations, and Final $p H$ Values Measured in the PCT Test

(Based on triplicate tests)

$\begin{array}{cccr}\text { Element } & \text { Top Sample } & \begin{array}{c}\text { Concentration, ppm } \\ \text { Bottom Sample }\end{array} & \text { EA glass } \\ \text { B } & 14 \pm 0.5 & 16 \pm 0.7 & 589 \pm 13 \\ \text { Li } & 15 \pm 0.6 & 17 \pm 0.7 & 193 \pm 3 \\ \mathrm{Na} & 44 \pm 1.5 & 49 \pm 2.0 & 1652 \pm 37 \\ \text { K } & 6 \pm 0.5 & 6 \pm 0.3 & \text { * } \\ \text { Si } & 102 \pm 2.1 & 111 \pm 4.5 & 845 \pm 10 \\ \text { Final pH } & 10.3 & 10.3 & 11.9\end{array}$

* There is no potassium in the EA glass

\section{Conclusions and Path Forward}

The Product Composition Control system (PCCS) successfully was used during the Tank 51 campaign to control both the process and the product. No processing problems were encountered during the campaign and the final glass composition was similar to that predicted by the PCCS, suggesting that the viscosity and liquidus had been properly controlled. Based on the results of the product Consistency Test, a durable glass was produced from the radioactive waste from Tank 51.

Further research in the Shielded Cells Facility will include vitrifying Batch 1 waste. As part of this campaign, the adjusted feed composition will be verified prior to vitrification.

\section{Beferences}

1 R. L. Postles and K. G. Brown, "The DWPF Product Composition Control System at Savannah River: Statistical Process Control Algorithm", Nuclear Waste Management IV, pp 559-568, American Ceramic Society, (1991).

2 C. J. Coleman, N. E. Eibler and R. A. Dewberry, "Analysis of High-Level Radioactive Sludges and Glasses at the Savannah River Site," Waste Management 190, pp 652-657, University of Arizona, Tucson, AZ (1990).

3 R. L. Postles and K. G. Brown, "PCCS SPC Algorithms for Waste Compliance," SCS-PMG-91-097, Savannah River Laboratory, Westinghouse Savannah River Company, Aiken, SC (1991). 
4 K. G. Brown, "Answer to Request for Erit Composition for 51-A," SRL-PMC-91-0009, Savannah River Laboratory, Westinghouse Savannah River Company, Aiken, SC (1991).

5 M. K. Andrews, N. E. Bibler, C. M. Jantzen and D. C. Beam, "Initial Demonstration of the DWPF Vitrification Process and Product Control Strategy Using Actual Radioactive Waste," Nuclear Waste Management IV, pp 569-576, American Ceramic Society, (1991).

6 C. M. Jantzen and N. E. Bibler, "Product Consistency Test (PCT) for DWPF Glass: Part I. Test Development and Protocil," DPST-87-575, Savannah River Laboratory, E.I. Du Pont de Nemours \& Co., Aiken, SC (1987). 

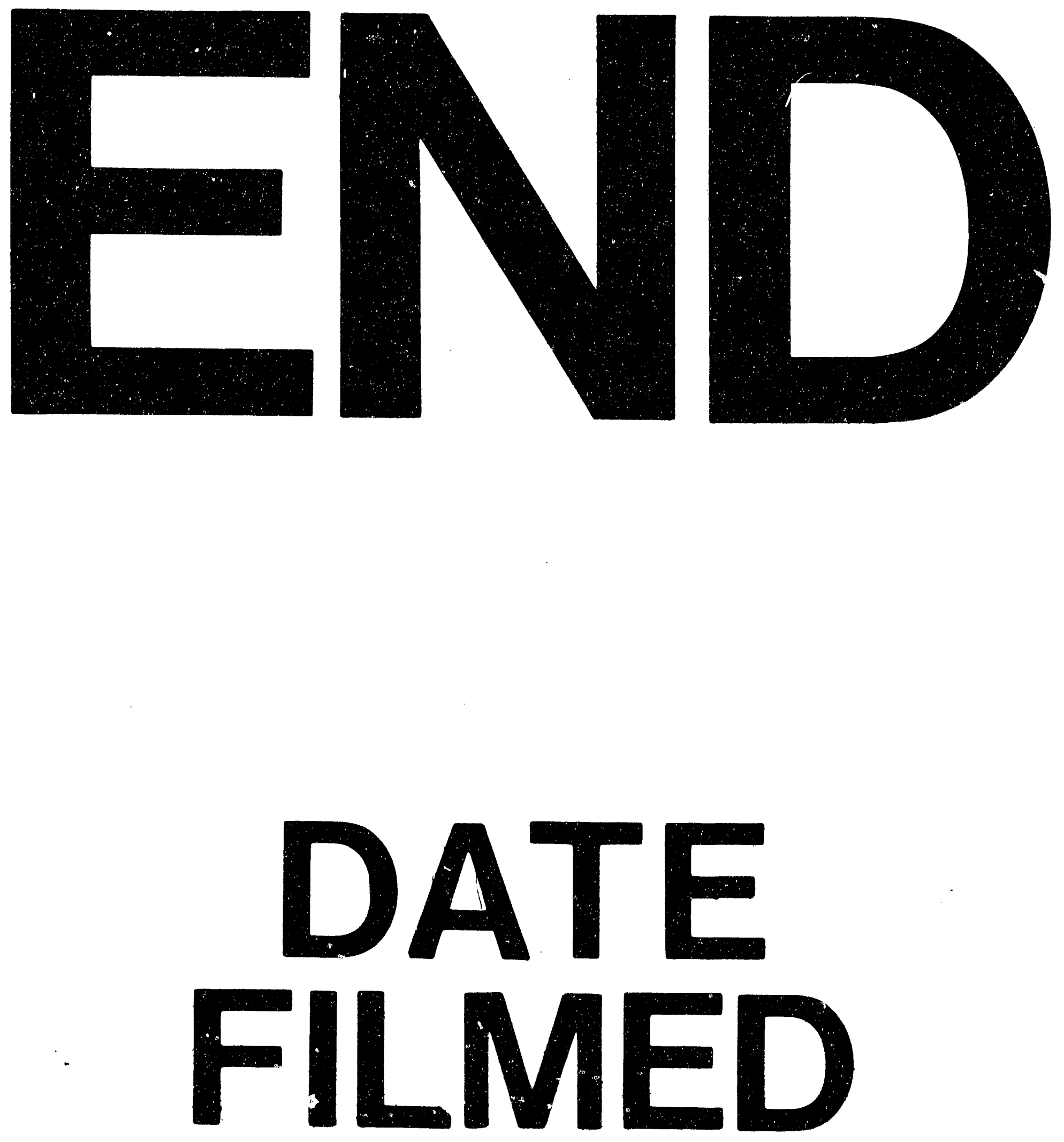

1

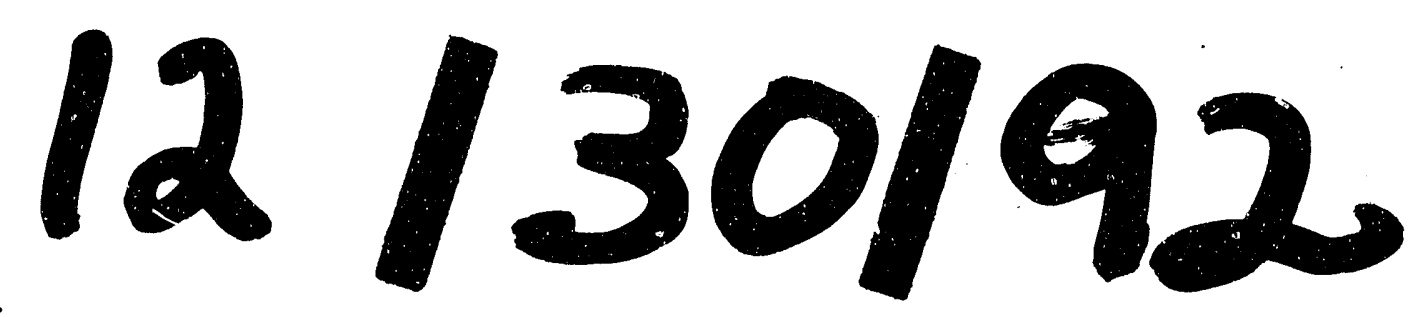


